\title{
Identifikasi Spasial Faktor-Faktor yang Mempengaruhi Permukiman Kumuh Di Kota Bekasi
}

\author{
Spatial Identification of Factors Affecting Slum Area in Bekasi City \\ Retno Wijayanti ${ }^{1}$, Atang Sutandi², dan Andrea Emma Pravitasari ${ }^{3}$
}

Diterima: 8 Juni 2019

Disetujui: 18 Juli 2020

\begin{abstract}
Abstrak: Kota Bekasi sebagai kota penyangga DKI Jakarta memiliki daya tarik yang tinggi bagi para pendatang untuk berurbanisasi. Hal tersebut memiliki konsekuensi timbulnya berbagai masalah perkotaan seperti berkembangnya permukiman kumuh. Penanganan permukiman kumuh di Kota Bekasi oleh pemerintah sudah dilakukan secara intensif sejak tahun 2016. Penelitian ini bertujuan mengidentifikasi permukiman kumuh di Kota Bekasi dan faktor-faktor yang mempengaruhi permukiman kumuh di Kota Bekasi. Metode penelitian menggunakan metode regresi linear berganda untuk mencari faktor-faktor yang mempengaruhi permukiman kumuh dan Geographically Weighted Regression (GWR) untuk dapat mengetahui faktor-faktor yang mempengaruhi permukiman kumuh secara lokal atau tiap wilayah kelurahan dengan menggunakan pembobot spasial. Hasil penelitian menghasilkan faktor yang diduga mempengaruhi permukiman kumuh di Kota Bekasi adalah jumlah titik kumuh tiap kelurahan, persentase anak penduduk miskin tidak sekolah, Indeks Perkembangan Kelurahan, jumlah Masyarakat Berpenghasilan Rendah, dan persentase bangunan hunian tidak memiliki Ijin Mendirikan Bangunan. Hal tersebut memperlihatkan faktor-faktor yang mempengaruhi permukiman kumuh di Kota Bekasi tidak hanya berupa faktor fisik, namun juga berupa faktor non fisik sehingga mengakibatkan meningkatnya persentase KK permukiman kumuh di Kota Bekasi. Berdasarkan hasil analisis GWR faktorfaktor yang mempengaruhi permukiman kumuh tersebut berbeda setiap waktu dan lokasinya.
\end{abstract}

Kata kunci: permukiman kumuh, regresi berganda, GWR

\begin{abstract}
Bekasi City is buffer city for Jakarta City which has high attraction for people to urbanize. It has consequences of the emergence of many urban areas issues such as slum area. The slums handling by the government has been running intensively since 2016. Objectives of the study were 1) Identify slum areas in Bekasi City 2) Analyze of key factors which affects slum area in Bekasi City. Data were analyzed using multiple linear regression methods to look for factors that affect slum area in Bekasi City and Geographically Weighted Regression (GWR) for find out the factors that affects slum area locally or each district using spatial weighting. The influenced factors of slum in Bekasi City were the number of slum in each district, the percentage of poor children who does not attending school, the value of district development index, the number of low-income people and the percentage of residential buildings without building permit. Based on the result of the study showed that the slums is not only influenced by the physical factors but also non physical factors caused the percentage of slum families increasing in Bekasi City. The GWR results showed the five factors above have different effects on each location.
\end{abstract}

Keywords: slum area, multiple regression, GWR

\footnotetext{
${ }^{1}$ Program Studi Ilmu Perencanaan Wilayah, Institut Pertanian Bogor

2 Departemen Ilmu Tanah dan Sumberdaya Lahan, Fakultas Pertanian, IPB

${ }^{3}$ Program Studi Ilmu Perencanaan Wilayah, Sekolah Pascasarjana; Departemen Ilmu Tanah dan Sumberdaya Lahan, Fakultas Pertanian, IPB
} 


\section{PENDAHULUAN}

Wilayah perkotaan di Indonesia telah berkembang sangat pesat dalam beberapa tahun terakhir. Kota besar seperti Jakarta dan wilayah sekitarnya akan terus berkembang, baik perekonomian maupun jumlah penduduknya yang akan berdampak pada penyediaan perumahan dan infrastruktur pendukung karena pertumbuhannya akan selalu di atas ratarata nasional (Joga 2017).

Jumlah penduduk terus bertambah dan lahan perkotaan yang dimanfaatkan semakin penuh sesak, sehingga kawasan perumahan dengan kepadatan tinggi di kawasan perkotaan terbentuk tanpa dapat dihindari (Kleniewski dalam Suhaeni 2010). Selain itu urbanisasi yang tinggi biasanya akan diikuti berbagai persoalan perkotaan seperti peluberan kota ke wilayah pinggiran serta kepadatan penduduk yang tinggi di tengah perkotaan atau biasa disebut kampung kota. Dalam kampung kota yang padat juga terdapat berbagai masalah yang berkaitan dengan lingkungan fisik dan kondisi sosial budaya penduduknya yang selanjutnya dapat menyebabkan munculnya permukiman kumuh (Budihardjo dalam Nursyahbani dan Pigawati 2015). Permukiman kumuh sendiri memiliki pengertian permukiman yang tidak layak huni karena ketidakteraturan bangunan, tingkat kepadatan bangunan yang tinggi, dan kualitas bangunan serta sarana dan prasarana yang tidak memenuhi syarat (KemenPUPR 2016).

Kota Bekasi sebagai salah satu kota penyangga DKI Jakarta telah berkembang pesat beberapa tahun terakhir. Faktor kedekatan lokasi dengan DKI Jakarta dan pertumbuhan ekonomi yang tinggi menyebabkan Kota Bekasi menarik bagi kaum pendatang untuk mencari kerja dan bermukim. Kota Bekasi merupakan lima besar kota dengan populasi terbesar di Indonesia. Dengan luas $210,49 \mathrm{~km}^{2}$ dan jumlah penduduk 2.888 .000 jiwa pada tahun 2017, Kota Bekasi kini berkembang menjadi permukiman kaum urban, sentra barang jasa dan industri di Jawa Barat (BPS 2017). Sama halnya terjadi di Kota Bekasi, pertambahan penduduk sebagai akibat dari urbanisasi yang tinggi memiliki konsekuensi timbulnya berbagai masalah perkotaan, seperti berkembangnya permukiman kumuh di Kota Bekasi. Adanya permukiman kumuh di Kota Bekasi telah menjadi isu strategis dalam perencanaan tata ruang Kota Bekasi (Distaru 2017).

Untuk menangani permukiman kumuh di Kota Bekasi, pemerintah telah mengupayakan penanganan permukiman kumuh secara simultan. Pemerintah pusat bersama-sama dengan Pemerintah Provinsi Jawa Barat dan Pemerintah Kota Bekasi telah melakukan penanganan secara intensif sejak tahun 2016. Teridentifikasi luas permukiman kumuh Kota Bekasi tahun 2016 sebesar 443 ha atau 2,1\% dari luas total Kota Bekasi yang tersebar pada 122 lokasi titik kumuh pada 56 kelurahan yang ada di Kota Bekasi (Disbangkim 2016). Sampai dengan tahun 2018 permukiman kumuh di Kota Bekasi telah tertangani dan berkurang luasannya sebesar 114,02 ha, di mana 9 kelurahan sudah bebas kumuh, sehingga permukiman kumuh luasnya berkurang menjadi 329,33 ha atau 1,56\% dari luas total Kota Bekasi (KOTAKU 2018).

Meski permukiman kumuh di Kota Bekasi sudah berkurang, sejauh ini faktor-faktor penyebab permukiman kumuh di Kota Bekasi belum diketahui secara pasti. Selain itu upaya penanganan permukiman kumuh di Kota Bekasi masih terlihat seragam, di mana anggaran yang tersedia digunakan untuk peningkatan infrastruktur kawasan permukiman kumuh, padahal faktor penyebab kekumuhan di wilayah Kota Bekasi tidaklah sama.

Untuk membantu merumuskan strategi penanganan permukiman kumuh di Kota Bekasi, penelitian ini bertujuan mengidentifikasi sebaran permukiman kumuh serta menganalisis faktor-faktor yang mempengaruhi permukiman kumuh di Kota Bekasi. Faktor-faktor yang mempengaruhi permukiman kumuh tersebut selain dianalisis menggunakan regresi berganda, juga dengan menggunakan analisis regresi dengan pembobot spasial sehingga nantinya diketahui faktor-faktor yang mempengaruhi permukiman kumuh tiap wilayah di Kota Bekasi. 
Penelitian mengenai faktor penyebab kumuh telah dilakukan oleh Sulestianson dan Indrajati (2013) menemukan bahwa faktor penyebab munculnya permukiman kumuh adalah kepadatan penduduk, rendahnya tingkat pendapatan, kurangnya kepedulian masyarakat terhadap lingkungan, kepadatan bangunan, status kepemilikan lahan dan prasarana permukiman yang buruk. Menurut Santosa dan Therik (2016) faktor penyebab permukiman kumuh adalah kondisi fisik bangunan dan sarana prasarana penunjang permukiman. Menurut Ramadhan dan Pigawati (2014) permukiman kumuh disebabkan karena kondisi bangunan rumah tinggal yang buruk, tingkat aksesibilitas kawasan, sanitasi lingkungan buruk, kondisi sosial ekonomi rendah.

Pada penelitian permukiman kumuh terdahulu faktor-faktor yang diduga mempengaruhi permukiman kumuh berlaku secara global atau keseluruhan wilayah dan hasilnya diberlakukan sama untuk tiap wilayah, sehingga masih menyulitkan ketika akan membutuhkan analisis lokasi yang mendetail untuk tiap wilayah. Pada kajian ini faktorfaktor yang mempengaruhi permukiman kumuh akan dianalisis kembali menggunakan metode Geographically Weighted Regression (GWR) untuk mendapatkan penduga variabel yang bersifat lokal untuk tiap wilayah. Menurut Pravitasari et al. $(2015 ; 2018)$ pemodelan spasial dengan teknik GWR dimaksudkan untuk mengeksplorasi variasi spasial terhadap hubungan antara variabel dependen dengan independen sehingga mampu menghasilkan visualisasi dan satu set regresi yang bersifat lokal.

Penelitian Nashwari et al. (2014) dengan pemodelan GWR mampu menjelaskan variabilitas respon yang memperhatikan efek spasial atau lokasi di mana keberadaan jalan dan program pemberdayaan masyarakat mempunyai pengaruh menurunkan kemiskinan tidak pada semua kabupaten namun hanya pada beberapa kabupaten. Melalui analisis GWR oleh Kurniasari dan Ariastita (2014) proses analisis faktor-faktor yang mempengaruhi alih fungsi lahan sawah di Kabupaten Lamongan dapat memunculkan hasil yang lebih spesifik terkait faktor yang bersifat lokal pada masing-masing lokasi dengan melihat keragaman antar wilayah.

Diharapkan kajian ini dapat memberikan gambaran faktor-faktor penyebab permukiman kumuh secara umum dan lokal tiap wilayah di Kota Bekasi sehingga dapat menjadi bahan masukan bagi Pemerintah Kota Bekasi dalam membantu penanganan permukiman kumuh secara efisien dan efektif sesuai dengan faktor-faktor yang mempengaruhi permukiman kumuh di Kota Bekasi serta membantu mengambil kebijakan untuk penanganan permukiman kumuh skala kota secara keseluruhan.

\section{METODE}

\section{Lokasi dan Waktu Penelitian}

Penelitian dilaksanakan di Kota Bekasi dengan titik koordinat pada $6^{0} 10^{\prime} 6^{\prime \prime}-6^{0} 30^{\prime} 6$ " LS dan $106^{\circ} 48^{\prime} 28^{\prime \prime}$ - 107027'29" BT. Wilayah Kota Bekasi seluas 210,49 km² dengan kondisi topografi relatif datar dan ketinggian 11-81 meter di atas permukaan laut (DPL). Penelitian ini dilaksanakan pada bulan Juni 2018 hingga April 2019.

\section{Bahan dan Alat}

Bahan yang digunakan berupa data sekunder yang diperoleh dari Satker KOTAKU Kota Bekasi, Disperkimtan Kota Bekasi, Distaru Kota Bekasi, Bappeda Kota Bekasi, BPS Kota Bekasi, dan BPN. Alat yang digunakan terdiri dari alat tulis, software ArcGIS 10.1, Google Earth, Statistica 7.0 dan Microsoft Office.

\section{Teknik Analisis Data} berikut :

Teknik analisis data yang digunakan untuk menjawab tujuan penelitian yaitu sebagai 


\section{Identifikasi Sebaran Permukiman Kumuh}

Analisis sebaran permukiman kumuh menggunakan data lokasi kumuh dan data baseline permukiman kumuh tahun 2016 dan 2018 dari KOTAKU. Peta permukiman kumuh dibangun menggunakan data spasial dan data titik lokasi kumuh serta pengurangan luas kumuh sampai dengan tahun 2018 dengan menggunakan Google Earth dan ArcGIS 10.1. Selanjutnya peta permukiman kumuh ditumpang susun dengan peta administrasi Kota Bekasi. Keluaran akhir berupa peta sebaran permukiman kumuh tahun 2016 dan 2018.

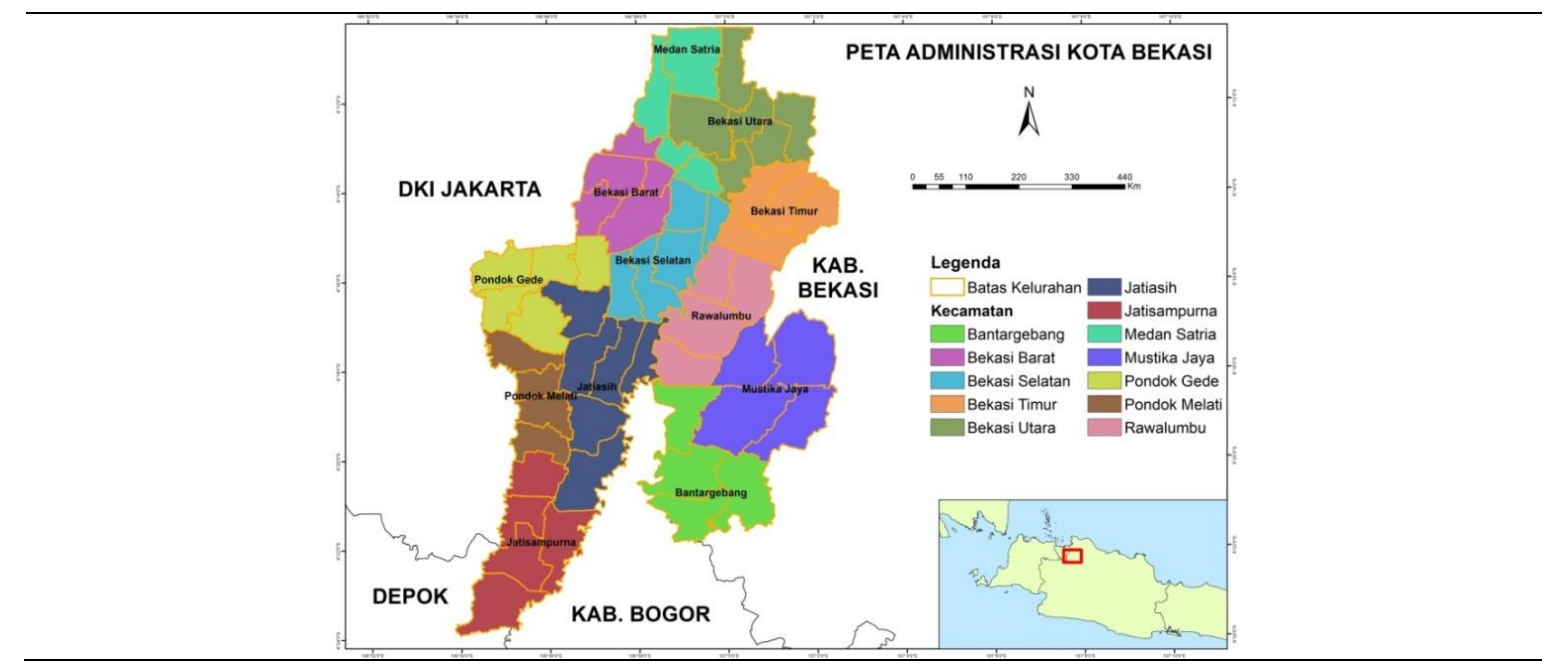

Gambar 1 Lokasi Penelitian

\section{Faktor-Faktor yang Mempengaruhi Permukiman Kumuh}

Dalam penelitian ini digunakan analisis regresi berganda untuk mengetahui faktorfaktor yang mempengaruhi permukiman kumuh secara umum dan analisis Geographically Weighted Regression untuk mengetahui faktor-faktor yang mempengaruhi permukiman kumuh secara lokal tiap wilayah. Analisis regresi linear berganda dilakukan sebelum analisis Geographically Weighted Regression (GWR), di mana terlebih dahulu akan diidentifikasi faktor-faktor yang mempengaruhi permukiman kumuh menggunakan analisis forward stepwise regression dengan Statistica 7.0. Pada kasus yang melibatkan banyak variabel bebas, pilihan regresi bertatar lebih cocok dan akan menghasilkan persamaan yang dibangun dari variabel bebas yang relatif saling bebas dan asumsi tidak adanya multikolinearitas terpenuhi (Panuju dan Rustiadi 2013). Variabel yang digunakan dalam analisis ini disajikan pada Tabel 1.

Tabel 1 Variabel untuk Analisis Faktor yang Mempengaruhi Permukiman Kumuh

\begin{tabular}{|c|c|c|}
\hline Faktor & Variabel & Definisi Operasional \\
\hline $\begin{array}{l}\text { Permukiman Kumuh } \\
\text { Fisik }\end{array}$ & $\mathrm{Y}$ & Persentase KK permukiman kumuh (KKKUM) \\
\hline Bangunan Gedung & $\mathrm{X}_{1}$ & Persentase bangunan dengan ketidakteraturan (BTTER) \\
\hline Sarana Prasarana & $\mathrm{X}_{2}$ & Panjang jalan lingkungan yang rusak (JALING) \\
\hline Lingkungan & $\begin{array}{l}X_{a} \\
X_{4}\end{array}$ & $\begin{array}{l}\text { Persentase luas kawasan terkena genangan (GEN) } \\
\text { Persentase KK dengan sarpras pengolahan sampah tidak memenuhi } \\
\text { persyaratan (SAMPAH) }\end{array}$ \\
\hline Non Fisik & & \\
\hline Lokasi dan Nilai & $X_{5}$ & Jumlah titik lokasi kumuh (JTKUM) \\
\hline Strategis Lokasi & $\begin{array}{l}\mathrm{X}_{6} \\
\mathrm{X}_{7}\end{array}$ & $\begin{array}{l}\text { Jarak kelurahan i ke pusat kota (JKOT) } \\
\text { Jarak kelurahan i ke jalan tol terdekat (JTOL) }\end{array}$ \\
\hline
\end{tabular}




\begin{tabular}{lcl}
\hline \multicolumn{1}{c}{ Faktor } & Variabel & \multicolumn{1}{c}{ Definisi Operasional } \\
\hline & $X_{9}$ & Jarak kelurahan i ke jalan arteri terdekat (JART) \\
& $X_{9}$ & Jarak kelurahan i ke rel kereta terdekat (JREL) \\
Sosial EKonomi & $X_{10}$ & Jarak kelurahan i ke sungai terdekat (JSUNG) \\
& $X_{11}$ & Persentase penduduk miskin/ pra sejahtera (PMIS) \\
& $X_{12}$ & Persentase anak penduduk miskin tidak bersekolah (APMTS) \\
Legalitas Bengunan & $X_{19}$ & Jumlah masyarakat berpenghasilan rendah (MBR) \\
Nilai IPK & $X_{14}$ & Persentase hunian tidak memiliki Ijin Mendirikan Bangunan (IMB) \\
Nilai Rataan ZNT & $X_{15}$ & Nilai Indeks Perkembangan Kelurahan (IPK) \\
\hline
\end{tabular}

Model regresi linear berganda yang digunakan :

$$
Y_{i t}=\beta_{0}+\beta_{1} X_{1 i t}+\beta_{2} X_{2 i t}+\beta_{3} X_{3 i t}+\beta_{4} X_{4 i t}+\cdots+\beta_{k} X_{\text {kit }}+\varepsilon_{i t}
$$

Dimana :

$Y_{i} \quad=$ Persentase KK permukiman kumuh ke-i

$\beta_{0}=$ Intercept

$\beta \quad=$ Koefisien regresi dari variabel bebas ke-i $\left(X_{i}\right)$

$X_{i} \quad=$ Variabel bebas ke-i

$\varepsilon_{i} \quad=$ Galat (error)

$\mathrm{t} \quad=$ Tahun

Setelah itu dilakukan analisis GWR dengan menggunakan software Geographic Information System (GIS) 10.1. Fotheringham et al. (2002) menyatakan model GWR adalah model regresi global yang diubah menjadi model regresi yang terboboti. Setiap nilai parameter model dihitung pada setiap titik lokasi geografis sehingga setiap titik lokasi geografis mempunyai nilai parameter regresi yang berbeda-beda. Formulasi model GWR dapat ditulis sebagai berikut:

$$
\begin{aligned}
& Y_{i t}=\beta_{o}\left(U_{i_{i}} V_{i}\right)+\beta_{\text {JTKUM }}\left(U_{i_{i}} V_{i}\right) X_{J T K U M i t}+\beta_{A P M T S}\left(U_{i_{2}} V_{i}\right) X_{A P M T S i t}+\beta_{M B R}\left(U_{i_{i}} V_{i}\right) X_{\text {MBRit }} \\
& \quad+\beta_{I M B}\left(U_{i_{i}} V_{i}\right) X_{\text {IMBit }}+\beta_{I P K}\left(U_{i_{i}} V_{i}\right) X_{\text {IPKit }}+\varepsilon_{i t}
\end{aligned}
$$

Dimana:

$Y_{i} \quad=$ Persentase KK permukiman kumuh kelurahan ke-i;

$\beta_{o}\left(U_{i}, V_{i}\right)=$ Intercept pada pengamatan ke-i;

$\beta_{1}, \ldots, \beta_{k}=$ Koefisien peubah masing-masing lokasi ke-i;

$\left(U_{i_{i}} V_{i}\right)=$ Koordinat letak geografis (longitude, latitude) kelurahan ke-i;

$\beta_{k}\left(U_{i,} V_{i}\right)=$ Koefisien regresi ke-k kelurahan ke-i;

$X_{\text {JTKUMi }}=$ Variabel jumlah titik kumuh kelurahan ke-i;

$X_{\text {APMTSi }}=$ Variabel persentase anak penduduk miskin tidak bersekolah kelurahan ke-i;

$X_{\text {MBRi }} \quad=$ Variabel Masyarakat Berpenghasilan Rendah (MBR) kelurahan ke-i;

$X_{I M B i}=$ Variabel persentase hunian tidak memiliki IMB kelurahan ke-i;

$X_{I P K i}=$ Variabel nilai Indeks Perkembangan Kelurahan (IPK) kelurahan ke-i;

$\varepsilon_{i} \quad=$ Galat (error) di tiap unit kelurahan ke-i;

$\mathrm{t} \quad=$ Tahun 2016 dan 2018 


\section{HASIL DAN PEMBAHASAN}

\section{Analisis Sebaran Permukiman Kumuh di Kota Bekasi}

Pada tahun 2016 permukiman kumuh yang ada di Kota Bekasi memiliki luas 443,34 ha atau 2,1\% dari total luas wilayah Kota Bekasi yang tersebar pada 122 titik lokasi kumuh pada 56 kelurahan sekota Bekasi. Setelah dilakukan penanganan pengurangan permukiman kumuh oleh pemerintah pusat bekerja sama dengan Pemerintah Kota Bekasi dari tahun 2016 sampai dengan 2018 permukiman kumuh telah berkurang sebanyak 114,02 ha sehingga permukiman kumuh luasnya menjadi 329,33 ha atau $1,6 \%$ total luas wilayah Kota Bekasi. Terlihat penanganan permukiman kumuh lebih terkonsentrasi di sekitar pusat kota atau di bagian utara dari Kota Bekasi seperti disajikan pada Gambar 2. Penanganan permukiman kumuh sampai tahun 2018 telah mewujudkan permukiman bebas kumuh pada 9 kelurahan di Kota Bekasi, yaitu Kelurahan Jatiluhur, Jatirasa, Jatimekar, Jaka Mulya, Kayuringin Jaya, Bintara Jaya, Kranji, Medan Satria dan Pejuang.

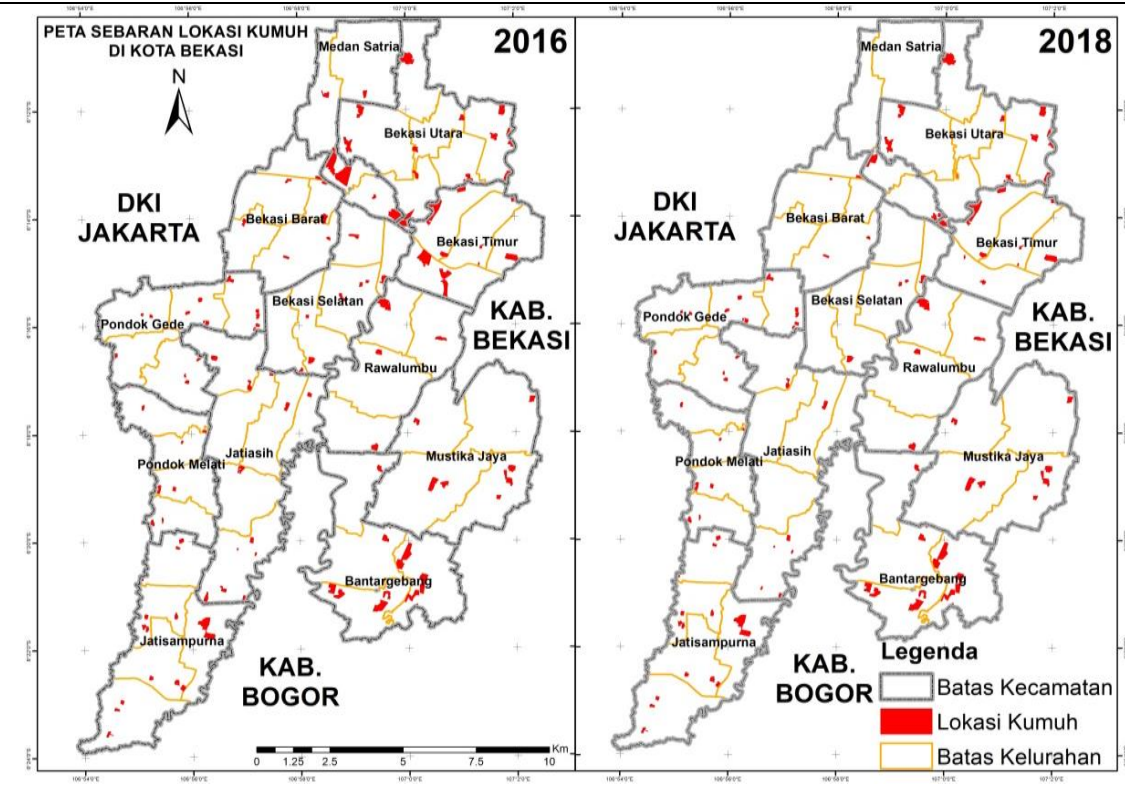

Gambar 2 Peta Sebaran Permukiman Kumuh di Kota Bekasi Tahun 2016 dan 2018

\section{Analisis Faktor-Faktor Yang Mempengaruhi Permukiman Kumuh di Kota Bekasi}

Faktor-faktor yang mempengaruhi persentase KK permukiman kumuh di Kota Bekasi dianalisis menggunakan regresi linear berganda dengan metode forward stepwise regression menggunakan software Statistica 7.0.

Tabel 2 Hasil Analisis Regresi Berganda

\begin{tabular}{|c|c|c|c|c|c|c|}
\hline \multirow[t]{2}{*}{$N=56$} & $\begin{array}{l}\text { Regression } \\
\mathrm{R}=.88414 \\
\mathrm{~F}(9,46)=1\end{array}$ & $\begin{array}{l}m \text { mary for } D \\
R^{2}=.781708 \\
3 p<0,00000\end{array}$ & $\begin{array}{l}\text { endent Var } \\
\text { Adjusted I } \\
\text { d.Error of }\end{array}$ & $\begin{array}{l}\text { le:Y }(\text { Persen } \\
.73899936 \\
\text { mate: } 2.510\end{array}$ & e KK Kum & 018) \\
\hline & Beta & Std.Err. & B & Std.Err. & $t(46)$ & p-level \\
\hline Intercept & & & -10.7630 & 2.925950 & -3.67847 & 0.000613 \\
\hline JTKUM & 0.626064 & 0.089790 & 2.0305 & 0.291208 & 6.97252 & 0.000000 \\
\hline IPK & 0.279494 & 0.074381 & 0.1544 & 0.041099 & 3.75761 & 0.000482 \\
\hline APMTS & 0.304334 & 0.083086 & 0.3906 & 0.106630 & 3.66287 & 0.000643 \\
\hline MBR & 0.183716 & 0.085368 & 0.0029 & 0.001331 & 2.15205 & 0.036675 \\
\hline PMIS & -0.131758 & 0.075193 & -1.5310 & 0.873712 & -1.75227 & 0.086391 \\
\hline
\end{tabular}




\begin{tabular}{|c|c|c|c|c|c|c|}
\hline \multirow[t]{2}{*}{$N=56$} & $\begin{array}{l}\text { Regression } \\
\mathrm{R}=.88414 \\
\mathrm{~F}(9,46)=18\end{array}$ & $\begin{array}{l}\text { mmary for } D \\
\mathrm{R}^{2}=.781708 \\
3 \mathrm{p}<0,00000\end{array}$ & $\begin{array}{l}\text { ndent Va } \\
\text { Adjusted } \\
\text { d.Error of }\end{array}$ & $\begin{array}{l}\text { le:Y (Persen } \\
.73899936 \\
\text { mate: } 2.510 \\
\end{array}$ & e KK Kum & 018) \\
\hline & Beta & Std.Err. & B & Std.Err. & $t(46)$ & p-level \\
\hline JALING & 0.130268 & 0.077617 & 0.0332 & 0.019768 & 1.67833 & 0.100064 \\
\hline IMB & 0.178893 & 0.085252 & 0.0371 & 0.017658 & 2.09842 & 0.041388 \\
\hline JTOL & -0.131828 & 0.092962 & -0.2927 & 0.206395 & -1.41807 & 0.162909 \\
\hline JREL & 0.126726 & 0.092725 & 0.1318 & 0.096460 & 1.36669 & 0.178366 \\
\hline
\end{tabular}

Hasil output Statistica menunjukkan nilai $R$-square sebesar 0,7389. Hal ini menunjukkan bahwa $73,89 \%$ keragaman persentase KK permukiman kumuh di Kota Bekasi dapat dijelaskan oleh variabel bebas, sedangkan sisanya sebesar $26,11 \%$ dijelaskan oleh variabel lain di luar model. Dari hasil analisis faktor-faktor yang mempengaruhi persentase KK permukiman kumuh $(\mathrm{Y})$ variabel bebas yang digunakan relatif signifikan pada tingkat kepercayaan $5 \%(\alpha=0,05)$ dan berpengaruh nyata dalam meningkatkan persentase KK permukiman kumuh yaitu jumlah titik kumuh tiap kelurahan (JTKUM), nilai Indeks Perkembangan Kelurahan (IPK), persentase anak penduduk miskin tidak bersekolah (APMTS), jumlah Masyarakat Berpenghasilan Rendah (MBR) dan persentase bangunan hunian tidak memiliki Ijin Mendirikan Bangunan (IMB). Didapat faktor-faktor yang diduga mempengaruhi peningkatan persentase KK Kumuh di Kota Bekasi merupakan faktor fisik dan faktor non fisik. Meningkatnya persentase KK permukiman kumuh kumuh di Kota Bekasi tidak hanya disebabkan faktor fisik berupa kurangnya infrastruktur perkotaan yang menyebabkan terjadinya titik-titik kumuh pada permukiman namun juga masalah non fisik berupa faktor sosial ekonomi, pendidikan dan lemahnya regulasi pendirian bangunan.

Faktor-faktor yang diduga mempengaruhi persentase KK permukiman kumuh di Kota Bekasi tersebut berlaku secara global atau di seluruh wilayah Kota Bekasi, sehingga masih menyulitkan ketika akan dianalisis pada wilayah mana faktor-faktor tersebut berpengaruh paling besar terhadap peningkatan KK permukiman kumuh tiap wilayah. Untuk mengetahui faktor-faktor yang mempengaruhi secara lokal atau tiap wilayah kelurahan, maka faktor-faktor yang signifikan tersebut dianalisis kembali menggunakan metode Geographically Weighted Regression (GWR). Dalam penelitian ini persentase KK permukiman kumuh digunakan sebagai variabel terikat/dependent (Y), sedangkan variabel bebas/independent menggunakan kelima faktor yang berpengaruh nyata tersebut.
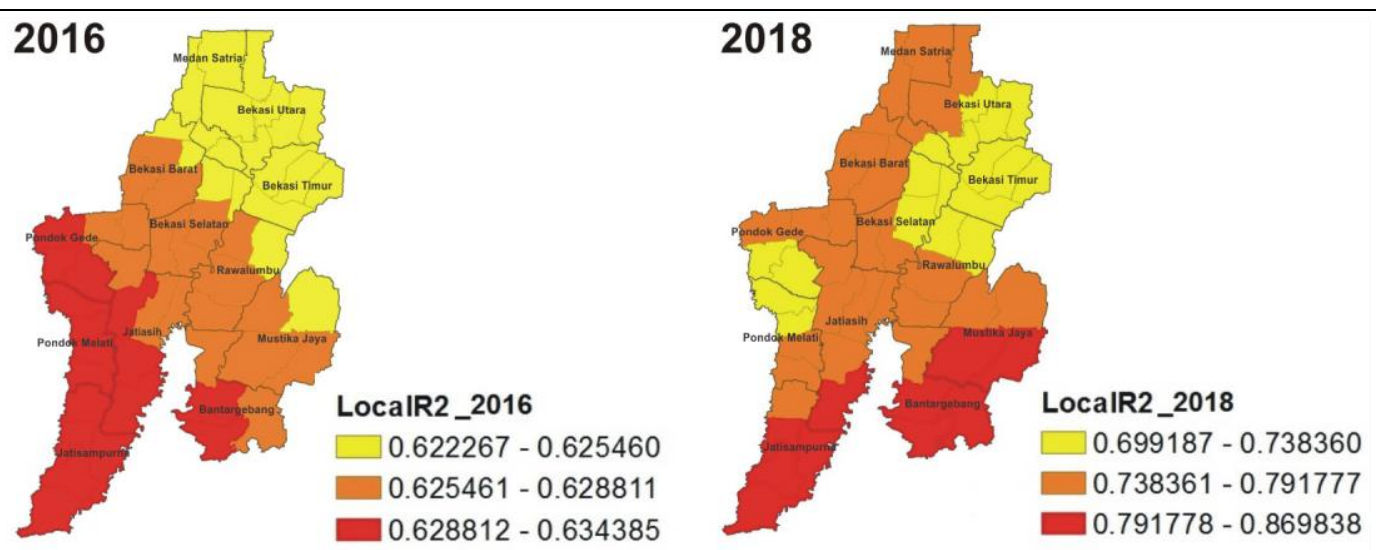

\section{Gambar 5 Peta Hasil GWR Tahun 2016-2018 di Kota Bekasi}

Berdasarkan hasil GWR pada Gambar 5, diperoleh nilai lokal $\mathbf{R}^{2}$ pada tahun 2016 berkisar $0,62-0,63$, sedangkan pada tahun 2018 nilai lokal $\mathbf{R}^{2}$ berkisar $0,70-0,87$. Nilai 
ini menunjukkan kemampuan model untuk menggambarkan faktor-faktor yang mempengaruhi permukiman kumuh, dalam hal ini persentase KK permukiman kumuh tiap kelurahan, yang dipengaruhi oleh faktor-faktor jumlah titik kumuh tiap kelurahan (JTKUM), nilai Indeks Perkembangan Kelurahan (IPK), persentase anak penduduk miskin tidak bersekolah (APMTS), jumlah Masyarakat Berpenghasilan Rendah (MBR) dan persentase bangunan hunian tidak memiliki Ijin Mendirikan Bangunan (IMB), pada masing-masing kelurahan sebesar $62 \%$ - 63\% pada tahun 2016 dan $70 \%$ - 87\% pada tahun 2018, sedangkan sisanya dijelaskan oleh faktor lain yang tidak termasuk dalam model ini. Pada model GWR setiap lokasi memiliki nilai $\mathrm{R}^{2}$ masing-masing atau sering disebut dengan istilah nilai lokal $\mathrm{R}^{2}$ (Rustiadi dan Hadi 2016). Secara keseluruhan model GWR tahun 2018 lebih baik daripada tahun 2016.

Pada tahun 2016 nilai lokal $\mathbf{R}^{2}$ paling tinggi berlokasi di bagian selatan dan barat daya wilayah penelitian, yaitu Kecamatan Pondok Melati, Jatisampurna, sebagian Kecamatan Pondok Gede, Jatiasih, Bantargebang yang ditunjukkan dengan warna merah, dan pada tahun 2018 nilai lokal $\mathbf{R}^{2}$ paling tinggi berlokasi di bagian tenggara-selatan wilayah penelitian yaitu di sebagian Kecamatan Jatiasih, Jatisampurna, Bantargebang dan Mustika Jaya. Wilayah dengan nilai lokal $\mathrm{R}^{2}$ yang lebih tinggi menandakan bahwa lima variabel yang digunakan dalam model mempunyai pengaruh yang besar terhadap persentase KK kumuh pada wilayah dengan warna merah daripada lokasi lainnya.

Berdasarkan hasil analisis GWR tahun 2016 dan 2018 didapatkan bahwa tingkat pengaruh dari setiap variabel berupa jumlah titik kumuh (JTKUM), nilai Indeks Perkembangan Kelurahan (IPK), persentase anak penduduk miskin tidak bersekolah (APMTS), jumlah Masyarakat Berpenghasilan Rendah (MBR), dan persentase bangunan hunian tidak memiliki Ijin Mendirikan Bangunan (IMB) yang ada pada permukiman kumuh berbeda pada setiap waktu dan lokasinya. Pada tahun 2016 urutan faktor-faktor yang berpengaruh terhadap persentase KK permukiman kumuh yaitu jumlah titik kumuh (JTKUM), nilai Indeks Perkembangan Kelurahan (IPK), persentase anak penduduk miskin tidak bersekolah (APMTS), jumlah Masyarakat Berpenghasilan Rendah (MBR) serta persentase hunian tidak memiliki Ijin Mendirikan Bangunan (IMB). Pada tahun 2018 urutan faktor yang berpengaruh yaitu jumlah titik kumuh (JTKUM), persentase anak penduduk miskin tidak bersekolah (APMTS), nilai Indeks Perkembangan Kelurahan (IPK), persentase hunian tidak memiliki Ijin Mendirikan Bangunan (IMB) serta jumlah masyarakat berpenghasilan rendah (MBR).

Dari hasil tersebut terlihat ketiga variabel yang paling mempengaruhi permukiman kumuh di Kota Bekasi adalah jumlah titik kumuh tiap kelurahan (JTKUM), persentase anak penduduk miskin yang tidak bersekolah (APMTS) dan nilai Indeks Perkembangan Kelurahan (IPK). Pada penelitian ini akan dibahas tiga variabel yang paling mempengaruhi peningkatan persentase KK kumuh di Kota Bekasi. Dalam model GWR ini variabel jumlah titik kumuh tiap kelurahan (JTKUM) merupakan variabel yang memiliki pengaruh paling besar dalam meningkatkan persentase KK permukiman kumuh. Hasil analisis GWR menunjukkan bahwa nilai koefisien atau parameter estimate (C) untuk variabel jumlah titik kumuh tiap kelurahan memiliki pengaruh yang paling besar dengan nilai koefisien positif pada tahun 2016 sebesar 0,46 - 0,47 seperti disajikan pada Gambar 6. Nilai positif menandakan bahwa meningkatnya jumlah titik kumuh pada tiap kelurahan akan meningkatkan persentase KK permukiman kumuh. Yang berarti pada tahun 2016 setiap kenaikan titik kumuh sebesar 1 unit maka akan meningkatkan persentase KK permukiman kumuh sebesar 0,46\% - 0,47\%. Pada tahun 2018 nilai koefisien mengalami peningkatan menjadi sebesar 0,63 - 2,89 artinya bahwa setiap kenaikan jumlah titik kumuh sebesar 1 unit maka persentase KK permukiman kumuh akan mengalami kenaikan sebesar $0,63 \%-2,89 \%$. 


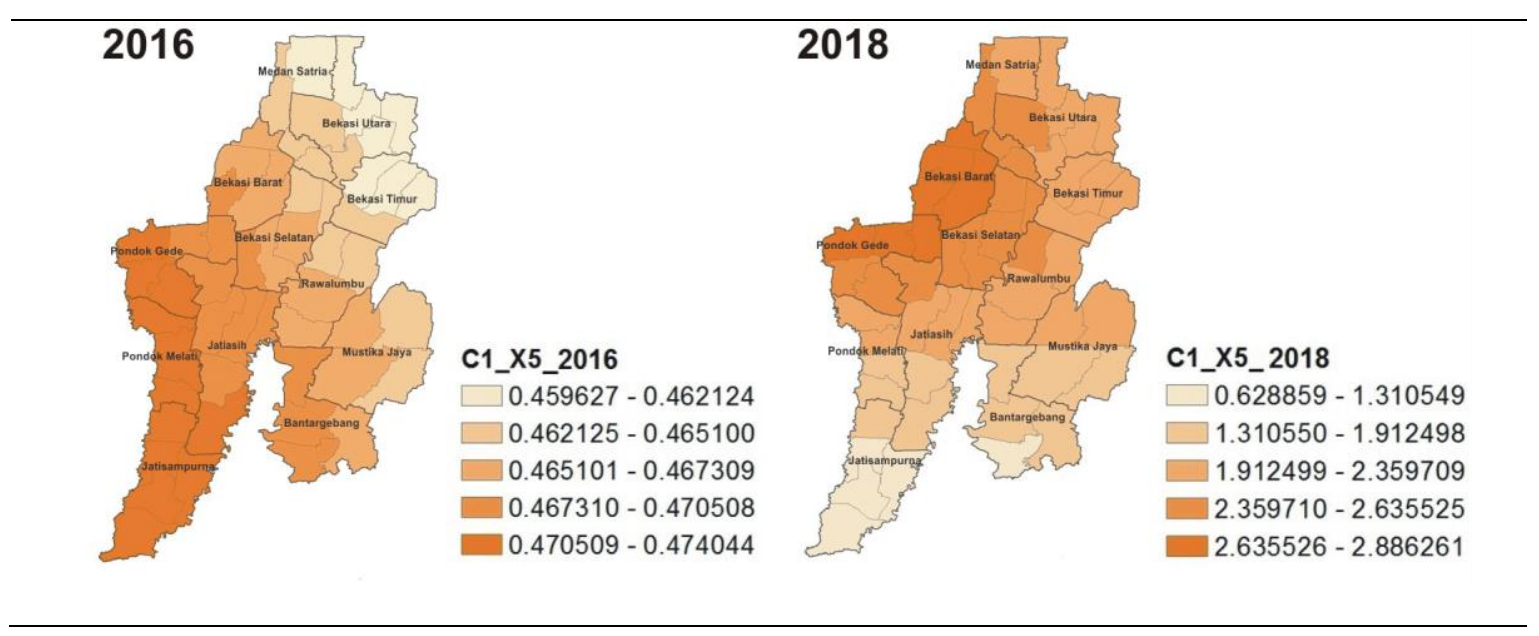

Gambar 6 Peta Hasil GWR Nilai Koefisien Jumlah Titik Kumuh (JTKUM) Tahun 2016-2018 di Kota Bekasi

Pada tahun 2016 wilayah yang memiliki pengaruh variabel jumlah titik kumuh paling tinggi, ditandai dengan warna oranye gelap, berada di wilayah barat daya Kota Bekasi yaitu Kecamatan Jatisampurna, Pondok Melati, sebagian Kecamatan Pondok Gede dan Jatiasih, sedangkan pengaruh jumlah titik kumuh terhadap persentase KK kumuh paling rendah terdapat di bagian utara Kota Bekasi. Pada tahun 2018 wilayah dengan warna oranye gelap berlokasi di sebelah barat laut Kota Bekasi, yaitu di Kecamatan Bekasi Barat dan sebagian Kecamatan Pondok Gede adalah lokasi di mana pengaruh variabel jumlah titik kumuh terhadap meningkatnya persentase KK permukiman kumuh paling besar, sedangkan pengaruh paling rendah berada di selatan Kota Bekasi, yaitu sebagian Kecamatan Jatisampurna dan Bantargebang.

Sebagaimana disajikan pada Gambar 3 variabel jumlah titik kumuh pada tahun 2016 dan 2018 memiliki pengaruh terbesar pada bagian barat daya dan barat Kota Bekasi, di mana wilayah ini berbatasan dengan DKI Jakarta. Dapat dilihat di sini peran lokasi yang strategis berbatasan dengan DKI Jakarta turut berpengaruh sehingga pada wilayah tersebut variabel jumlah titik kumuh memiliki pengaruh besar dalam meningkatkan persentase KK kumuh. Kota Bekasi saat ini masih sebagai hinterland bagi DKI Jakarta sehingga Kota Bekasi cenderung dikonotasikan sebagai dormitory town (Distaru 2017). Untuk masyarakat yang tidak dapat mengakses hunian yang layak, mereka akan menempati hunian apa saja yang bisa didapat asalkan dekat dengan lokasi kerja, meskipun hunian tersebut tidak layak huni. Selain itu wilayah barat Kota Bekasi termasuk wilayah dengan kepadatan penduduk tinggi.

Variabel jumlah titik kumuh (JTKUM) menjadi faktor yang berpengaruh paling besar dalam meningkatkan persentase KK Kumuh di Kota Bekasi sehingga penanganan permukiman kumuh di Kota Bekasi akan lebih efektif dengan melakukan pengurangan jumlah titik kumuh pada wilayah prioritas yang memiliki coeffisient parameter tinggi atau wilayah yang memiliki gradasi warna oranye gelap (Kecamatan Bekasi Barat dan sebagian Kecamatan Pondok Gede).

Variabel persentase anak penduduk miskin tidak bersekolah (APMTS) pada tahun 2018 merupakan faktor urutan ke-2 yang mempengaruhi permukiman kumuh, dalam penelitian ini memiliki nilai koefisien positif pada tahun 2016 sebesar 0,16-0,17 dan pada tahun 2018 sebesar 0,20 - 0,52 seperti disajikan pada Gambar 7. Nilai positif menandakan meningkatnya persentase anak penduduk miskin tidak bersekolah pada suatu wilayah akan berbanding lurus dengan peningkatan persentase KK permukiman kumuh. Artinya pada tahun 2016 setiap kenaikan persentase anak penduduk miskin tidak bersekolah sebesar 1\% maka akan meningkatkan persentase KK permukiman kumuh sebesar 0,16\% - 0,17\%. Sedangkan pada tahun 2018 setiap kenaikan persentase anak penduduk miskin tidak 
bersekolah sebesar 1\% maka akan meningkatkan persentase $\mathrm{KK}$ permukiman kumuh sebesar 0,20\% - 0,52\%. Variabel ini pada tahun 2016 memiliki pengaruh terbesar yang ditandai dengan warna coklat gelap, di bagian selatan Kota Bekasi, yaitu di Kecamatan Mustika Jaya, Bantargebang dan sebagian Kecamatan Jatisampurna. Pada tahun 2018 pengaruh paling besar di wilayah bagian selatan, yaitu di Kecamatan Jatisampurna dan sebagian Kecamatan Pondok Melati, Jatiasih dan Bantargebang. Terlihat variabel persentase anak penduduk miskin tidak bersekolah berpengaruh besar pada wilayah yang berbatasan dengan Kabupaten Bekasi, Kabupaten Bogor dan Kota Depok. Wilayah dengan warna kuning muda menunjukkan variabel persentase anak penduduk miskin tidak bersekolah memiliki pengaruh yang rendah terhadap meningkatnya persentase $\mathrm{KK}$ permukiman kumuh. Pada tahun 2016 wilayah dengan pengaruh rendah berada pada bagian utara dan barat laut Kota Bekasi, dan pada tahun 2018 di barat Kota Bekasi.
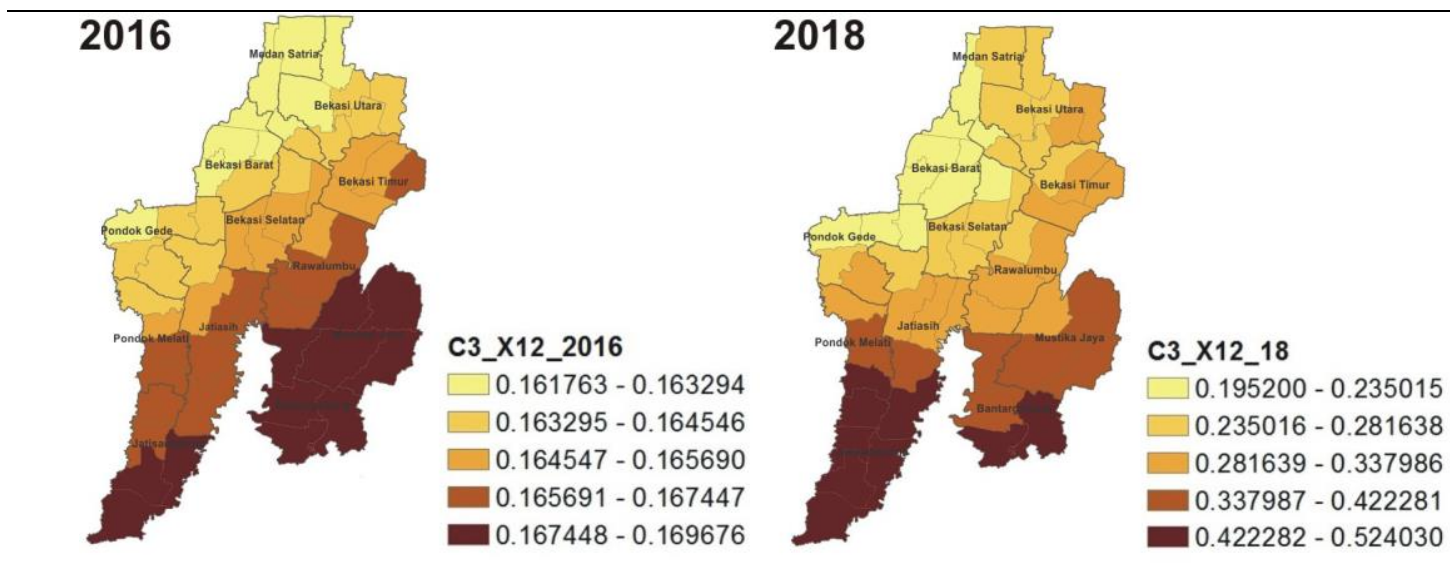

Gambar 7 Peta Hasil GWR Nilai Koefisien Anak Penduduk Miskin Tidak Bersekolah (APMTS) Tahun 2016-2018 di Kota Bekasi

Hasil analisis GWR tersebut menunjukkan bahwa permukiman kumuh di Kota Bekasi dipengaruhi oleh faktor non fisik berupa faktor pendidikan dan sosial ekonomi masyarakat yang mendiami permukiman kumuh tersebut dengan pengaruh paling besar di selatan Kota Bekasi. Variabel anak penduduk miskin tidak bersekolah yang bertempat tinggal di permukiman kumuh di bagian selatan Kota Bekasi memiliki pengaruh paling besar dalam meningkatkan persentase KK permukiman kumuh dibandingkan pada wilayah lainnya di Kota Bekasi. Permukiman kumuh pada wilayah selatan Kota Bekasi merupakan permukiman kumuh dengan kepadatan sedang hingga rendah dengan lokasi sebagian besar berada pada zona permukiman dan campuran.

Masyarakat yang bermukim di permukiman kumuh mayoritas merupakan penduduk miskin atau termasuk dalam golongan masyarakat dengan pendapatan $40 \%$ ke bawah serta berpendidikan rendah. Variabel anak penduduk miskin tidak bersekolah berpengaruh besar terhadap meningkatnya persentase KK permukiman kumuh diduga berkaitan dengan Angka Partisipasi Kasar (APK) atau proporsi anak sekolah untuk jenjang tertentu pada usia tertentu pada tingkat sekolah dasar sederajat di Kota Bekasi masih lebih rendah (106,11\%) dibanding APK sekolah dasar Provinsi Jawa Barat $(109,42 \%)$ (Bappeda 2018).

Rendahnya pendidikan masyarakat yang bertempat tinggal di permukiman kumuh berakibat pada rendahnya kepedulian terhadap kualitas lingkungan hunian yang mereka tempati serta menjadi penyebab ketidakdisiplinan perilaku hidup bersih dalam masyarakat, seperti membuang sampah, hajat dan limbah rumah tangga sembarangan sehingga menyebabkan lingkungan menjadi kumuh. Pendidikan yang rendah menyebabkan 
tingginya permasalahan sanitasi seperti rumah tangga tidak memiliki jamban, septictank, dan pola hidup bersih tidak diterapkan. Penanganan permukiman kumuh untuk faktor anak penduduk miskin tidak bersekolah akan lebih efektif mengurangi persentase KK kumuh dengan prioritas penanganan pada wilayah yang memiliki gradasi warna coklat gelap atau di wilayah selatan Kota Bekasi (Kecamatan Jatisampurna dan sebagian Kecamatan Pondok Melati, Jatiasih dan Bantargebang).

Variabel urutan ke-3 yang mempengaruhi persentase permukiman kumuh di Kota Bekasi adalah Variabel Indeks Perkembangan Kelurahan (IPK). Variabel ini merupakan hasil dari analisis tingkat perkembangan wilayah di Kota Bekasi. Nilai Indeks Perkembangan Kelurahan (IPK) dihitung dari ketersediaan jumlah dan jenis fasilitas dan prasarana yang terdapat pada suatu kelurahan serta rasio jumlah fasilitas terhadap jumlah penduduk. Variabel IPK dalam penelitian ini tahun 2016 memiliki nilai koefisien positif sebesar 0,18 - 0,19 dan tahun 2018 memiliki nilai koefisien positif sebesar 0,1 - 0,25 seperti disajikan pada Gambar 8. Artinya pada tahun 2016 di Kota Bekasi setiap kenaikan nilai IPK sebesar 1 unit maka akan meningkatkan persentase KK permukiman kumuh sebesar 0,18\% - 0,19\%. Sedangkan pada tahun 2018 setiap kenaikan nilai IPK sebesar 1 unit maka akan meningkatkan persentase KK permukiman kumuh sebesar 0,1\% - 0,25\%.

Pada penelitian ini wilayah dengan IPK tinggi di Kota Bekasi justru berbanding lurus dengan peningkatan persentase KK permukiman kumuh. Wilayah dengan sarana dan prasarana perkotaan yang lebih lengkap akan menarik pendatang untuk bekerja dan bermukim di wilayah tersebut. Hal ini disebabkan wilayah dengan IPK tinggi merupakan wilayah yang berkembang, terdapat di pusat-pusat kota yang perekonomiannya relatif maju atau di wilayah yang menjadi pusat pelayanan bagi wilayah-wilayah di sekitarnya, yang ditandai dengan sarana prasarana perkotaan yang lengkap. Dengan adanya pusat-pusat ekonomi tersebut para pendatang akan dimudahkan untuk mencari mata pencaharian di tempat tersebut dan cenderung untuk memilih hunian dekat dengan tempat kerjanya meski hunian tersebut kurang layak. Dari hasil analisis GWR wilayah dengan warna hijau gelap menandakan pengaruh variabel IPK terhadap persentase KK permukiman kumuh adalah yang paling besar. Baik pada tahun 2016 dan 2018 lokasi dengan pengaruh yang paling besar hampir sama lokasinya, di bagian utara Kota Bekasi yaitu sebagian Kecamatan Medan Satria dan Bekasi Utara di mana lokasi tersebut berada dekat dengan pusat Kota Bekasi.

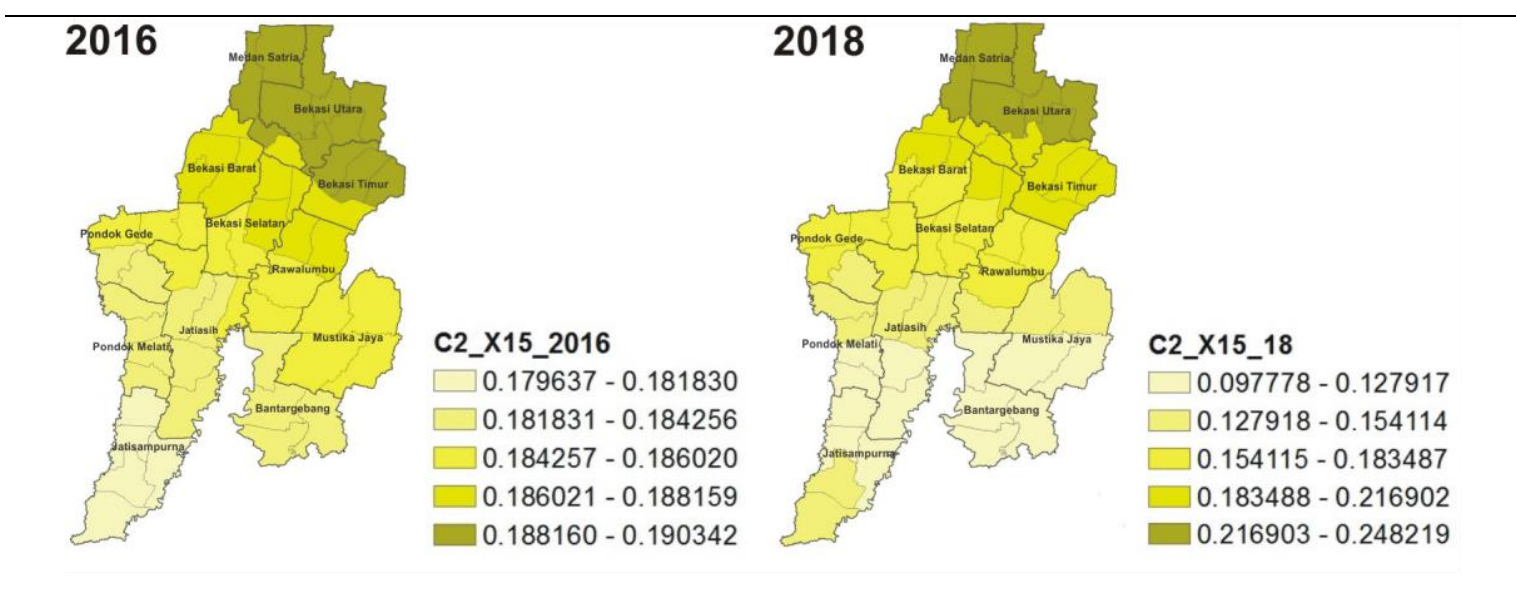

\section{Gambar 8 Peta Hasil GWR Nilai Koefisien Indeks Perkembangan Kelurahan (IPK) Tahun 2016-2018 di Kota Bekasi}

Wilayah utara Kota Bekasi merupakan wilayah dengan hirarki II dan III. Menurut Rencana Tata Ruang Wilayah Kota Bekasi bagian utara Kota Bekasi merupakan zona 
perumahan dengan kepadatan tinggi dan sudah lebih dulu berkembang perumahan dan permukimannya daripada wilayah-wilayah lainnya di Kota Bekasi (Distaru 2017). Pada wilayah dengan variabel IPK berpengaruh besar terhadap peningkatan persentase KK permukiman kumuh, ketersediaan infrastruktur dan sarana prasarana perkotaan tidak sebanding dengan jumlah penduduk yang berdiam di wilayah tersebut. Ketersediaan sarana kesehatan, sarana pendidikan, sarana perekonomian tidak sesuai dengan rasio jumlah penduduk yang bermukim pada wilayah tersebut sehingga berpotensi menimbulkan kekumuhan.

Dari analisis GWR ketiga faktor yang diduga paling berpengaruh meningkatkan persentase KK kumuh di Kota Bekasi menunjukkan bahwa faktor-faktor yang mempengaruhi permukiman kumuh di Kota Bekasi berbeda menurut waktu dan lokasinya. Dari ketiga faktor tersebut pada tahun terakhir penelitian, faktor jumlah titik kumuh (JTKUM) berpengaruh paling besar di wilayah timur Kota Bekasi (Kecamatan Bekasi Barat dan sebagian Kecamatan Pondok Gede), faktor jumlah penduduk miskin berpendidikan rendah (APMTS) berpengaruh paling besar di wilayah selatan Kota Bekasi (Kecamatan Jatisampurna dan sebagian Kecamatan Pondok Melati, Jatiasih dan Bantargebang) serta faktor Indeks Perkembangan Kelurahan (IPK) berpengaruh paling besar di wilayah utara Kota Bekasi (Kecamatan Bekasi Utara dan Medan Satria). Terlihat tingkat pengaruh faktor penyebab meningkatnya persentase KK permukiman kumuh di Kota Bekasi berbeda-beda pada setiap wilayah. Faktor penyebab permukiman kumuh berpengaruh sama besar pada setiap wilayah.

Didapat meningkatnya persentase KK permukiman kumuh kumuh di Kota Bekasi tidak hanya disebabkan faktor fisik namun juga faktor non fisik serta hasil dari analisis GWR di mana tiap faktor memiliki pengaruh berbeda pada tiap wilayah diharapkan dapat menjadi masukan untuk strategi penanganan permukiman kumuh di Kota Bekasi secara efektif. Mengingat keterbatasan anggaran pemerintah pusat maupun pemerintah daerah dalam penanganan permukiman kumuh perkotaan, alternatif penanganan permukiman kumuh dapat ditentukan berdasar faktor penyebab permukiman kumuh di mana penanganan permukiman kumuh disesuaikan dengan faktor-faktor yang mempengaruhi permukiman kumuh secara lokal atau memiliki tingkat pengaruh paling besar pada wilayah tersebut.

Untuk mengurangi persentase KK permukiman kumuh di Kota Bekasi, penanganan permukiman kumuh untuk pengurangan jumlah titik kumuh berupa peningkatan kualitas permukiman kumuh serta pembangunan rusunawa bagi masyarakat berpenghasilan rendah dapat diprioritaskan pada wilayah barat Kota Bekasi atau pada wilayah yang berbatasan dengan DKI Jakarta (Kecamatan Bekasi Barat dan sebagian Kecamatan Pondok Gede). Penanganan permukiman kumuh pada sektor non fisik atau sektor pendidikan untuk anak penduduk miskin tidak bersekolah berupa penyelesaian program pendidikan dasar sembilan tahun, program pendidikan non formal serta edukasi hidup sehat dapat diprioritaskan pada wilayah selatan Kota Bekasi (Kecamatan Jatisampurna serta sebagian Kecamatan Pondok Melati, Jatiasih dan Bantargebang). Penanganan permukiman kumuh pada faktor penyebab permukiman kumuh berupa Indeks Perkembangan Kelurahan (IPK) dengan dengan penambahan fasilitas kesehatan, pendidikan, perekonomian serta pembangunan infrastruktur permukiman supaya tercapai rasio sarana prasarana permukiman dengan jumlah penduduk dapat diprioritaskan pada wilayah utara Kota Bekasi (Kecamatan Medan Satria dan Bekasi Utara).

\section{KESIMPULAN}

Berdasarkan hasil penelitian yang telah dilaksanakan maka dapat diambil kesimpulan sebagai berikut. Sebaran permukiman kumuh pada tahun 2016 (sebelum penanganan) menunjukkan luasan permukiman kumuh terbesar berada di pusat kota, sedangkan pada tahun 2018 (setelah penanganan) berada di wilayah selatan Kota Bekasi. 
Hal tersebut disebabkan penanganan permukiman kumuh sampai dengan tahun 2018 diprioritaskan di pusat kota, sedangkan pada wilayah selatan Kota Bekasi kurang mendapatkan penanganan permukiman kumuh secara terpadu.

Permukiman kumuh di Kota Bekasi dipengaruhi oleh faktor fisik maupun non fisik berupa jumlah titik kumuh tiap kelurahan, persentase anak penduduk miskin tidak bersekolah, nilai Indeks Perkembangan Kelurahan (IPK), jumlah masyarakat berpenghasilan rendah (MBR) dan persentase bangunan hunian tidak memiliki Ijin Mendirikan Bangunan (IMB). Hasil GWR menunjukkan masing-masing faktor yang mempengaruhi permukiman kumuh di atas memberikan tingkat pengaruh yang berbedabeda pada setiap waktu dan lokasinya.

\section{DAFTAR PUSTAKA}

[BPS] Badan Pusat Statistik Kota Bekasi. 2017. Kota Bekasi dalam Angka. Bekasi: BPS Kota Bekasi.

[Disbangkim] Dinas Bangunan dan Permukiman Kota Bekasi. 2016. Surat Keputusan Walikota Bekasi Nomor 600/ Kep. 376.A_Disbangkim/VI/2016 tentang Lokasi Permukiman Kumuh di Kota Bekasi. Bekasi: Dinas Bangunan dan Permukiman Kota Bekasi.

[Distaru] Dinas Tata Ruang Kota Bekasi. 2017. Revisi Rencana Tata Ruang Wilayah (RTRW) Kota Bekasi Tahun 2011-2031. Bekasi: Dinas Tata Ruang Kota Bekasi.

Fotheringham A.S, Brundson C, Charlton M. 2002. Geographically Weighted Regression The Analysis of Spatially Varying Relationships. England (UK): John Wiley and Sons Ltd.

Joga N. (2017) Mewariskan Kota Layak Huni. Jakarta: Gramedia.

[KemenPUPR] Kementerian Pekerjaan Umum dan Perumahan Rakyat. 2016. Peraturan Menteri Pekerjaan Umum dan Perumahan Rakyat Nomor 2/PRT/M/2016 tentang Peningkatan Kualitas Terhadap Perumahan Kumuh dan Permukiman Kumuh. Jakarta: Kementerian Pekerjaan Umum dan Perumahan Rakyat.

[KOTAKU] Satuan Kerja Kota Tanpa Kumuh Kota Bekasi. 2016. Dokumen Baseline Permukiman Kumuh Kota Bekasi. Bekasi: Satuan Kerja Kota Tanpa Kumuh (KOTAKU).

Panuju DR, Rustiadi E. 2013. Teknik Analisis Perencanaan Pengembangan Wilayah. Bogor: Departemen Ilmu Tanah dan Sumberdaya Lahan, Fakultas Pertanian. Institut Pertanian Bogor.

Pravitasari AE, Saizen I, Tsutsumida N, Rustiadi E, Pribadi DO. 2015. Local Spatially Dependent Driving Forces of Urban Expansion in an Emerging Asian Megacity: The Case of Greater Jakarta (Jabodetabek). International Journal of Sustainable Development 8(1):108-119.

Pravitasari AE, Rustiadi E, Mulya SP, Setiawan Y, Fuadina LN, Murtadho A. 2018. Identifying The Driving Forces of Urban Expansion and its Environmental Impact in Jakarta-Bandung Mega Urban Region. IOP Conf. Series: Earth and Environmental Science 149 (2018) 012044. doi:10.1088/17551315/149/1/012044.

Rustiadi E, Hadi S. 2016. Dampak Kecenderungan Konurbasi Jakarta-Bandung terhadap Alih Fungsi Lahan Pertanian dan Lingkungan. Laporan Akhir Penelitian Unggulan Sesuai Mandat Pusat. Kemenristekdikti, Pusat Pengkajian Perencanaan dan Pengembangan Wilayah (P4W-LPPM), Institut Pertanian Bogor.

Nashwari IP, Rustiadi E, Siregar H, Juanda B. 2016. Analisis Spasial Kelembagaan Petani dan Kemiskinan Petani Tanaman Pangan menggunakan Geographically Weighted Regression di Provinsi Jambi. Majalah Ilmiah Globe 18(2):83-94.

Nursyahbani R, Pigawati B. 2015. Kajian Karakteristik Kawasan Pemukiman Kumuh di Kampung Kota (Studi Kasus: Kampung Gandekan Semarang). Jurnal Teknik PWK 4(2):267-281.

Santosa EB, Therik LV. 2016. Faktor Penentu Bertempat Tinggal pada Kawasan Kumuh di Kota Malang. Jurnal Tataloka 18(4):261-273.

Ramadhan RA, Pigawati B. 2014. Pemanfaatan Penginderaan Jauh untuk Identifikasi Permukiman Kumuh Daerah Penyangga Perkotaan (Studi Kasus: Kecamatan Mranggen Kabupaten Demak). Jurnal Geoplanning 2(1):102-113

Kurniasari M, Ariastita PG. 2014. Faktor-Faktor yang Mempengaruhi Lahan Pertanian Sebagai Upaya Prediksi Perkembangan Lahan Pertanian di Kabupaten Lamongan. Jurnal Teknik Pomits 3(2):119-124.

Suhaeni H. 2010. Tipologi Kawasan Perumahan Dengan Kepadatan Penduduk Tinggi dan Penanganannya. Jurnal Permukiman 5(3):116-123.

Sulestianson E, Indrajati PN. 2013. Penanganan Permukiman Kumuh dengan Pendekatan Karakteristik dan Faktor Penyebab Kekumuhan (Studi Kasus: Permukiman Kumuh di Kelurahan Tamansari dan Kelurahan Braga. Jurnal Perencanaan Wilayah dan Kota BSAPPK 3(2):261-270. 